\title{
The effects of MFA quota elimination on Indian fibre markets
}

\author{
Authors: Jagadanand Chaudhary ${ }^{a}$; Samarendu Mohanty ${ }^{a}$; Sukant Misra ${ }^{a}$; Suwen Pan a \\ Affilation: " Department of Agrieutural and Applied Economics, Texas Tech University, Lubbock. TX, USA
}

DOI: $10.1080 / 00036840600771205$

Publication Frequency: 24 issues per year

Published in: $\rightarrow$ Applied Economics

First Published on: 30 August 2007

\begin{abstract}
This articie examines the effects of multi-fibre arrangement (MFA) quota elimination on Indian fibre market. The partial equilibrium Indian fibre model was developed using a theoretically consistent framework and incorporated regional supply response, substitutability between colton and man-made fibres, and appropriate linkage between colton and textile sectors. Baseline projections were developed for supply, demand and prices of cotton, man-made fibres and textiles under a set of exogenous assumptions. The effects of MFA textile quota eliminations were introduced into the model by conducting three scenarios, J.e. increasing textile exports by 10,20 and $30 \%$ from the baseline level. The results suggest that on an average, cotton imports rise by $4-8 \%$ annually, while the man-made fibre exports from India decline with the opering of textile markets in the developed countries. The higher domestic cotton prices encourage acreage expansion in colton in all the three regions in india, but not enough to meet rising mill dernand under the scenarios of higher textile exports. The rise in cotton imports from India has little effect on world colton prices.
\end{abstract}

\section{Introduction}

India has the largest cotton-producing area in the worid, accounting for $25 \%$ of the world acreage. However, India's contribution to the world proctuction is estimated to be around $14 \%$, primarily because of low yield. In the last decade, cotton production in India has increased only $8 \%$, whereas consumption has risen by more than $35 \%$. The increase in cotton consumption is primarily driven by strong textile consumption and exporls. The textile exports during this period increased on an averaga of $19 \%$ per annum. The disparity between the colton production and consumption tumed India from a nat exporter into a net importer of cotton. Since 1999 , India has accounted for $6 \%$ of the world colton imports.

India's re-energence as a major cotton importer has occurred mainly because of external and internat consirainis. The external constraint was the multi-fibre arrangernent (MFA), which provided a framework under which developed cauntries abided by a quota on the export of yam, textiles and apparel from the developing countries. These bilateral quatas have restricted Indian exports of cotton textile products ln which it has a strong comparative advantege. Established in 1974, MFA allowed for discrimination not only against specific fibres and products, but also among exporting countries. Under Uruguay Round/General Agreement on Tariff and Trade (UR/GATT), Agreement on Textile and Clothing (ATC) started phasing out MFA within 10 years periad since 1995, and atl bilateral quotas were eliminated on i January 2005.

Many sturties project that India will ba a major benefidary of MFA textle qudta eliminations, wilh lextle exports expanding by as much as $25 \%$. In addition, domestic lextile constumptien is also expected to increase rapidly in the future sofar as the international monetary fund (IMF) and the Wortd Benk project the thdian economy to grow at $6-8 \%$ annually in the medium-term. The projected strong growth in textile exports and domestic consumption woutd lead to the expansion of mill denand for cotton, necessitating an increase in colton production at a much faster pace than the historical rate of less than $1 \%$ annually. Since cotton acreage is unlikely to expand in the future, production growlh will have to cone through yield inprovements.

Very few studies have examined the future of the Inctian fibre merket under the scertario of MFA quota efimination and its ettects on the wortd fibre market. However, these studies have either falled to take into account substitutzillity between cotton and man-made fibres, or appropriate tinkage between colton and textiles, thus producing incomplete assessment of the elimination of MFA qudia on the Indian cotton matket and the world fibre market. More specifically, it is criticat to develop better understanding of the effects of MFA quota eilmination on Incilis's and world fibre markets.

The objective of this study is to develop an empirical framework that Incorporates regional supply respense, substitulabllity between cotton and man-made fibres, and appropriate llnkage between cotton and textile sectors to measure the effects of MFA quota eilminations on the Indian and world fibra markets. This is achieved by developlng a partial equilibrium structural econometric modet of Indian fibra markets. Partial equilibrium structural policy simulation models have been exiensively used in the past for policy anzalysis (Fuller et al., 1999, Koo, 2002; Devadioss and Wathl, 2004).

The remainder of this article is organized as follaws. The next section davelops a conceptual tramework of various components of the Indian colton model that are critical to a conteptual analysis of the evaluation of the elimination of MFA quota. We then devatop a pertial equilibrium structural econometric modiel of indian fibre markets to measura the effects of MFA quota ellminations on Indian cotton trade. This is followed by a description of the date. Policy simulations along with their implications are presented next. Finelly, wa make concluding remarks.

\section{Conceptual Framework}

This section starts with the graphical representation of the potential impacts of the MFA quola ellmination on the tndian and wortd colton markets. The graphical analysis presented in Fig. 1 shows the expected directional changes to the Indian and world colton markats, in a price-quantity space, dua to MFA quota elimination. As shown In Fig. 1, panels (a) and (b) represent Indian textile and cotton markat respectively. Panel (d) represents the rest of the world (ROW) cotton market, whereas penel (c) shows the market ctearing mechanism at the world leved by equating excess supply with excess derrand. Transportation cost efiects are ignored for simplicity. 


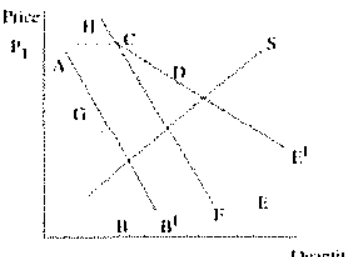

(a) Jexlite mathit in tmida Thtarilil!

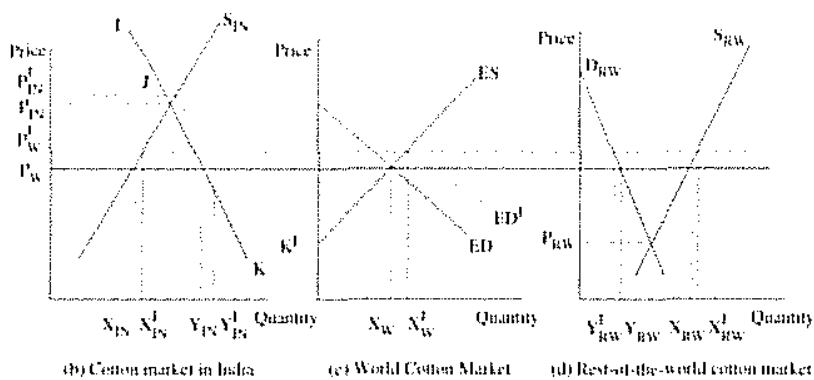

[Enlarge Image]

Fig. 1. Impacts of MFA quota elimination on world cotton and textile markets.

Indian cotton demand is derived from the textile market in panel (a). AGB' and HCDE' ara the export demand and total demand for Indian textiles, where total demand is a horizontal summation of export and domestic demand (HCF). As shown in the diagram, export demend for textiles is zero at or above the price $P_{\mathrm{T}}$. In this renge, total textile demand is same as the domestic consumption. However, as the price falls below $P_{T}$ export demand becomes positive and ls added to tha domestic demand; thus the total textile demand curve is kinked and is represented by HCDE!'

The presenca of MFA quotes limit textle exports to ceriain markats causing the textile export demand kinked at G to becorne AGB. This, tn turn, resuits in kinked total textie dernand, HCDE. Since the domestic catton demand in pane (b) is derived from tha total textile demand and the latter is kinked, this results in kinked colton demand curve tepresented by IJK. Panel (c) displays the wordd market equilibrium with excess suppiy, ES, derived from the ROW in panel (d), and excess dernand, ED, from the Indian cotion market fin panel (b), yielding a world caton price of $P_{W}$. At this world price, India's caton imports ate $\left(Y_{\mathbb{N}}-X_{1 N}\right)$, and ROW cattan exports are $\left(X_{\mathrm{RW}}-Y_{\mathrm{R}}\right)$, and both ere equal to $X_{W}$, the volume traded in warld cotton market.

With the elimination of MFA, the textile export demand stifts to AGB' in panel (a), an increase in export dernand, resulting in an outward shitt in the total textile demand from HCDE to HCDE'. The rise in textile demand, in turn, increases the mill demand for colton In lindia with the cotion dernand curva shifting from IJK to IJK' in panel (b). The rise in ealton demand in

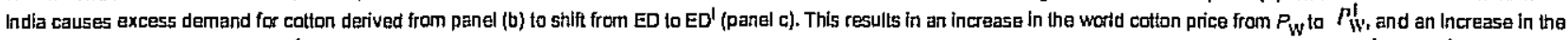

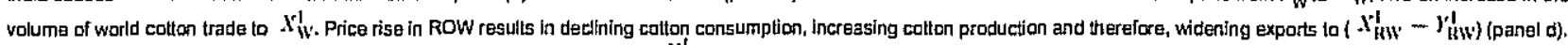
Higher prices results in an expansion of colton production in India from $X_{\mathrm{IN}}$ to $X_{\mathrm{iN}}^{\prime}$; however, due to increase in textile consumption cotton dernand Increases more than its production, thus, cotton imports expands to $\left\{\gamma_{\mathrm{IN}}^{1}-x_{\mathrm{N}}^{\prime}\right\}$ (pant b).

If the representalion of the market5 depicted in Fig, 1 is reasonably accurate then the expected effects of textile quata ellimination would be to increase indian textile exporis, Indian cotton imports, wordd catton price and increase cotton exports from theROW. However, the conceptual analysis does not, and cannot, reveal the magnitude of these expected effects. For this purpose, a partial equilibrium structural econometric model of Indlan fibre markets is developed to measure the effects of MFA quata eliminations an Indian cotton Irade. Schematic representation of the Indlen fibre model, which depicts the reiationships among different cornponents of the model, is presenied in Fig. 2. The framawork inciudes supply, dentand and price linkages equations for cotton and man-mada fibres.

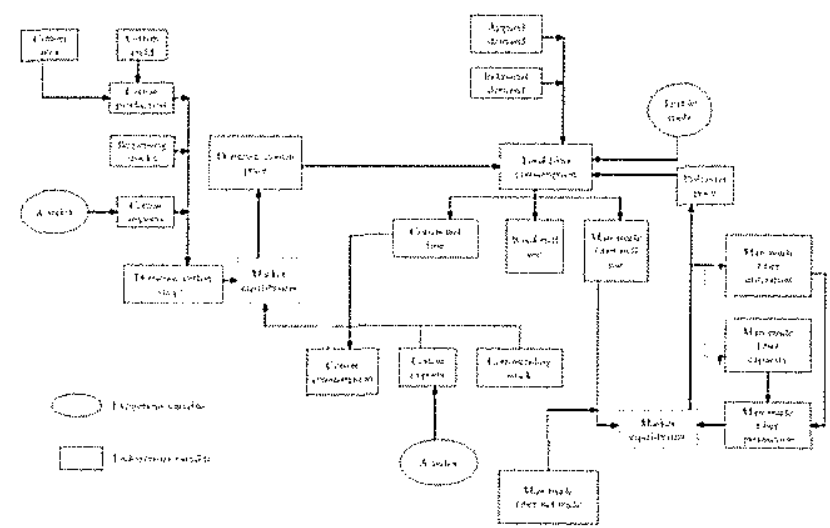

[Enlarge Image]

Fig. 2. Schematic representation of the Indian fibre model

As shown in the dlagram, acreage and yield levels contribute to cotton production, which builds up total domestic supply after incorporating beginning stocks and Imporis. Indien colton supply responses are estimated In a regional famework consisting of four regions in order to account for heterogeneity in growing conditions arising out of cilmatic differentes and 
avallablity of water and other natural resources that influence the mix of crops in each of the regions.

This structurat model of the Indian fibre model alsa takes into account Inter-fibre competition amang fibres such as cotton and woal, and man-made fibres at the mill level. Thls aliows substitution between cotion and man-made fibres based an their relative prices. Mill utilization of each fibre is estimated In two sieps: (1) total lextile consumption and (2) its allocation among various fibres such as cotton, man-mede fibres, and other thres based an the telative prices. Thus, the second step yields domestic mill use demands of cotton, wool and manmade fibre in the Indian fbre modiel. Colton ending stocks and cotion trade must also be teken inio account in the cotton compenent in ordet to ciose the model. Total cotton supply and tatal cotian demand in equilibrium determine the domestic caltan price. Total cotton demend includes domestic mill utilization, ending stocks and axports

Simliaty, man-made fibre production is estimated as the product of capacity and utilization rate. Man-made fibre production and man-made fibre demand, domestic mill use and net trate combined, determine matket clearing conditians for the man-made fibre sector. This enables to solve the man-mada fibre price endagenously in the modal to allow inter-fibre substitution at the mill level. Finelly, worid colton price (A-index) enters into the model through cotton trada equations.

\section{Model Specification Fibre supply estimation}

In this study, the tndian colton-producing area is segregated into four regiens in order to account for heterogeneity in growing conditions arising out of cimatic differences, avallablity of water and other natural resousces that influence the mix of crops in each of the regions. The four regions include north, central, sauth and the rest of india. The ith region acreage response is specified as:

$$
\wedge C_{i, t}=f\left(\mathrm{EPC}_{i, l}, \mathrm{EPCM}_{i, t}, A \mathrm{C}_{i, l-1}\right)
$$

where $i=$ north, central, south and the olhers regions in India. $\mathrm{AC}_{i t}$ Is the cotton acreage in ith ragian in time $t$ in thousand hettares; EP $\mathrm{C}_{i, t}$ represent5 expected cotton price in ith region in time $t$, EPCM $_{i, t}$ are the expected prices of competing crops in the th region in time $t$.

Competing crops for the northern region include wheat, rice and rapeseed; for the central region, Include sugarcane, groundnut, rapeseed and wheat, while groundnut, com, sugarcane and rice are the competing crops for the southern region. The area devoted to cotion is expected to be positively related to the price of cotton and negatively related to the prices of competing crops. Expected prices are calculated es the weighted average of the current year's minimum support price and tast year's average market prices for the corresponding craps.

Cotlon yield is spacified as follows.

$$
\mathrm{YC}_{t, t}=f\left(\mathrm{EPC}_{i, t}, \mathrm{YC}_{i, t-1}, \mathrm{RF}_{i}, \mathrm{~F} \Lambda_{t,}, T_{t}\right)
$$

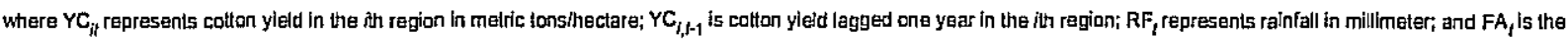
fertilizer application in kghectare. Once cotton area and yield have been estimated, cotton production can be caiculated by mulliplying area by yield and sum over al! four regians:

$$
\mathrm{CPR}_{t}=\sum_{i=1}^{+} \wedge \mathrm{C}_{i, t} \times \mathrm{Y}^{\mathrm{r}} \mathrm{C}_{i, t}
$$

where CPR, fepresents tatal cotton production In India In time periad $t$.

Man-made fibre production capacity is specified as a function of polyester and crude oil prices, lagged 3-6 years, and man-made fibre production capacity, lagged 1 year.

$$
\mathrm{MMPC}_{t}=f\left(\mathrm{PP}_{t-k}, \mathrm{PO}_{t-k}, \mathrm{MMPC}_{t-1}\right)
$$

Where MMPC, represents the man-mada fibre productive capacity at time $t_{i} P_{t-k}$ is the lagged price of polyester; $P_{t-k}$ is the lagged price of petroleum cruda all; MMPC $t_{t-1}$ represents the man-made tibse productive capacity at time $t-1$, and $k=3, \ldots, 6$.

Man-made fibre capacity utilization is specified as the function of polyester and crude vil prices, and utilization rate lagged 1 year:

$$
\mathrm{MMCUZ}_{t}=f\left(\mathrm{PP}_{t}, \mathrm{PO}_{t}, \mathrm{MMCUZ}_{t-1}, T\right)
$$

Where MMCUZ, is the man-made fibre capacity utilization in period $t$.

\section{Fibre demand estimation}

As discussed in the conceptual framework, fibra demand is derived using a two-step process. In the first step, consumers allocala expendiltures io a broad group of commodities, i.e. per capita textile consumption in fibre equivalent in India is estimated and then allocated among various fibres in the sacond stage.

Textile consumption (per capita textile demand in fibre equivalent) is specified as the function of textie price index, food price fncex, per capite real income and time trend:

$$
\mathrm{TXPC}_{t}=f\left(\mathrm{PTX}_{1}, \mathrm{PFD}_{t}, I_{l}, T\right)
$$

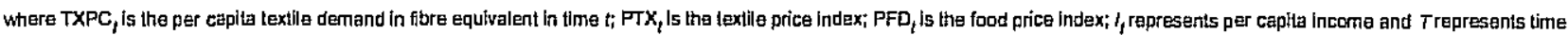
trent. Becausa of aconomic expansion, consumers will have higher disposable income resulting in elevaled purchasing power, and higher demand for various products, including textiles and clothing. Thus, textile consumption is hypothesized to be positivaly related to income. In addition, econamic theory suggests that consumption of a good is Inversely related to its own price and positively related to the prices of competing goods. Thus, textile consumption is expacted to have an inverse relationship with the textle price index and a direct relationship with the food price index. Equation 6 is estimated by using the ordinary least square (OLS) method.

In the second stage, the share of each of the fibres in the textile consumption framework is estimated using linear approximation/almost ideal demand system (LA/AIDS), (Deaton and Muelibayer, 1980). The empirical LAIAIDS model for the cotton, man-made fibre and wool shares for Indian textiles is spectied as toliows:

$$
\begin{aligned}
\mathrm{SC}_{t}= & \alpha_{1}+\gamma_{11} \log \left(\mathrm{PC}_{t}\right)+\gamma_{12} \log \left(\mathrm{PMF}_{t}\right) \\
& +\gamma_{13} \log (\mathrm{PW})+\beta_{1} \log \left(\frac{F}{P^{*}}\right)+t_{1 t}
\end{aligned}
$$




$$
\begin{aligned}
\mathrm{SMF}_{1}= & \alpha_{2}+\gamma_{21} \log \left(\mathrm{PC}_{1}\right)+\gamma_{22} \log \left(\mathrm{PMF}_{t}\right) \\
& +\gamma_{2} \log \left(\mathrm{PW}_{t}\right)+\gamma_{2} \log \left(\frac{\gamma^{\prime}}{p^{*}}\right)+u_{t} \\
\mathrm{SW}_{t}= & \alpha_{3}+\gamma_{31} \log \left(\mathrm{PC}_{t}\right)+\gamma_{2} \log \left(\mathrm{PMF}_{t}\right) \\
& +\gamma_{13} \log \left(\mathrm{PW}_{t}\right)+\beta_{3} \log \left(\frac{\gamma^{*}}{P^{*}}\right)+u_{3 t}
\end{aligned}
$$

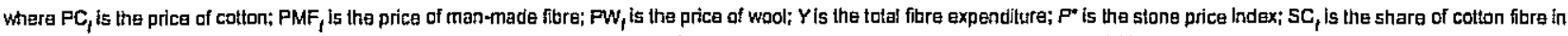
the lexile; SMF, is the share of man-made fibre and SW, represents the share of wook. Uncompensated and the compensated elasticities, as well as the expenditure elasticities in the LA/AlOS model will be computed from the estimated coefficients using the formtila given by Green and Alston (1990).

\section{Cotton ending stocks and trade equations}

Cotton ending stocks can be specified as the function of domestic coiton price, cotton production and beginning stocks.

$$
\mathrm{CES}_{l}=f\left(\mathrm{PC}_{t}, \mathrm{CES}_{t \rightarrow 1}, \mathrm{CPR}_{t}\right)
$$

Whare CES is the cotton ending stocks. Both beginning stocks and cotton prociuction variables are expected to have a direct relationship with ending slocks; at the same time, the catton market price is expected to have an inverse relationship with ending stocks. Equation to is estimated using the OLS method.

Cotton export in Indla is speciffed to depend on reiative prices between domestic and world markets, and cotton supply. The exchange rate is not modelled explicitly here, but it is capturad in the model by expressing International price in domestic currency afier acjusting for expost tax:

$$
\mathrm{CEX}_{t}=f\left(\mathrm{PC}_{t} \cdot \mathrm{PA}\left(\mathrm{I}-\mathrm{ET}_{t}\right) \mathrm{XR}_{i} \cdot \mathrm{CSU}_{t}\right)
$$

Where CEX, is the export of cotten; $\mathrm{PA}_{f}$ is the international cotton price represented by A-index c.j.f. North Europe; CsU, is the cotton supply; ET, the export tax on colton in percentage and $X R_{f}$ is the exchange rate of US doliars inta Indian currency. Colton exporls should increase with a risa in intemational catton prices relative to diomestic price and vice versa. In addition, a graater supply of cotton means that more cotton can be exported owing to high international prica, thus a direct relationship is hypathesized between supply of cotton and export of cottan. The cotton export equation is estimated using the OL.S method.

The catton import equation is specified as the function of the relative domestic price of cotton wilh respect to the intenational price, adjusted for the import tariff and income.

$$
C I M_{t}=f\left(\mathrm{PC}_{1}, \mathrm{P \Lambda _{t }}\left(\mathrm{I}+\mathrm{IT}, \mathrm{XR}_{t}, \mathrm{I}_{t}\right)\right.
$$

whera $C_{1} M_{t}$ is the import of cotton at time $t ; T_{f}$ is the import tarifi rate in tndia in percentage and gross domestic product represents the proxy far income $\left(I_{l}\right)$ in India. It is assumed that as If Increases and the international prices of cotion relativa lo domestic price decrease, colton import demand should increase; that is, more cotton fibre will be imported. The cotton Import equation is estimated by the OLS method.

\section{Market clearing condition}

Baffes and Ajwad (2001) found that volume of trade relative to the slze of demesic consumption is an important factor in determining the degree of inkage batween the domestic and the world price. Since indian catton trade is very small relative to the damestic consumption, it seemed appropriale to solve damestic cotton price by adding an identity equation to solve the system of demand and supply equations. The equillbrium condition exisis at the potnt where total cotton consumption Is equal to total collon supply in lindia. This can be spectifed as in the following equation:

$$
C P R_{t}+\mathrm{CES}_{t-1}+\mathrm{CIM}_{t}=\mathrm{DC} C_{t}+\mathrm{CES}_{t}+\mathrm{CEX}
$$

Similarly, the man-made fibre market clearing condition inciudes production, consumption and net trada. Since ending stocks data is not available, it is assumed that stock does not chenge from year to year.

$$
M M P R_{t}=\mathrm{DMF}_{t}+\mathrm{MMTR}
$$

Where MMPR, represents man-made fibre production, which is obtalned through multiplying man-made fibre capacity utilization with its capacity; DMF, is the man-made fibre consumplion, and $M M T R_{f}$ Is the man-mada fibre net trade (exports-imports).

All the above equatians except those of LAVADS madels are estrmated using OLS. A battery of statistical methods is used to test whether the assumptions of normal, independent and identically cistributed (NIID) error terms ara violated and whether these violations cause a bias in their estimators. The assumpton of homoskedastic conditional variance is tested using the White's test. For testing whether the errors are linear with respect to the condilioning variables, the respecification error test (RESET) developed by Rernsey is used. To test the assumplion of a nomal conditional distribution, the skewness kurtosis (SK) test, the Shapiro-Wik (5W) test, and a graph of the conditional distribution with a normal curve overiay are used. The LAAIDS model for share of fibre Is estimated first withoul any restrictions and later, imposing adding-up, homogeneify and symmetry restrictions combined. The arror temms across the equations in LAAIDS modis ara correlated by the fact that the dependent variables need to salisfy the budget constraint. Consequenily, the OLS estimates of these equalions would be inconsistent and biased. Therefore, seemingly unrefated regressions (SUR), which provide more efficient estimates are used instead. In the first slage, OLS is used to estimate the variance-covariance matrix among the residuals, while in the second stage, the estinated matrix is used In a generalized least squeres estimation. Imposing of the edding-up restriction makes the variance-covariance matrix for the disturbances singular, thus, nensingularity is maintained by deleting the equatien of ROW from the fibre share emplsical LA/AIDS model. The parameters associated with the amitted demand equation are recovered later on by making use of the restrictions. Correction for autocomelation is tione in the estimation of parameters, and a nontinear algorithm is used for the estimation of tha LA/AIDS model. All the equations ara estimated using SAS (SAS Version 9.1, 2002-2003).

\section{Data}

Data were coilected from various sources. Macroeconomic variables for India such as gross damestic product (GDP), population, exchange rata, GDP deflator and the average spot price of crude oil were obtained from 'International Financial Statistics' published by the IMF. Coiton A-index price, us 1.5 denier polyester price, and US farm price sheer wool (greasy basis) were collected from Cotton and Wool Yearbook of Economic Research Service, Uníted States Depertment of Agriculture (ERS, USDA). Prices of polyester staple fitra and cotton fibre, and colton tarifilduty in Indla were obtained from Foreign Agricultural Service, USDA and the Textije Commissioner's Office, Govemment of India (GOI). Minimum support price lor colton and competing crops were obtained from the website of India's Ministry of Agricullure (avaitable online at http:Jlagricoop.njc.Jn/statisticsi). The textile price index was gathered from the Hancbook of Industrial Policy and Statisites 200t, tracia; at the same time, wholesale price index for food was obtained from the Handbook of Statistics on lndian Econemy, 2001 on CD- 
ROM. Both indices were originally available on 1970/1971 and 1981/19B2 base years, which were converted to1993/1994 base year for consistency. The textile price index for tha year 1982-t984 was missing and had to be interpalated. The producer price for cotton and competing crops was obtained from the databasa of Food end Agricultural Organizetion (FAO). The consumer price index was gathered from the Ministry of Finance, GOl. Total fibre consumption, total cotion consumption and total man-matie fibre constumption were obtained from the FASIUSDA, and the Textile Commissioner's Office, GOI. Wool and other fibre consumption wera calculated by subbracting cotion and man-made from total fibra consumption. Similarly, man-made fibre capacity, utilization and man-made fibre production were also collacled from the same sources.

Data for cotton suppty and demand were obtained trom the Foreign Agrieultural Services of the United States Department of Agriculture (FAS/USDA). The databese consists of cotton area, yield, proditetion, imports, exporis, ending stocks and total domestic consumption. The area, yield and production data for colton at the state tevel were obtained from the FAS/USDA, indiastat.com and the Minisiry of Agriculture, India on-lise. The yield data for competing crops at the state lavel were gathered from the Centre for Monitoring Indian Ecanomy, and the Directory of Indlan Agriculture, 1997. Fertilizer consumption wes obtained fant the Centre for Monitaring Indlan Econony. The percentage of coverage under irrigation was collected from the Department of Agriculture and Cooperatives, India (availeble ontine at http:l/agricoop.nic.In/statistlcsi), whille rainfall data was coilected from lindiastat.com. Aithough the data were obtained from various sources, these were cross-checked for consistency.

\section{Policy Simulations}

The estimated model was used to develop baseline projactions for Indian fibre demand, supply and prices for ten-year period under a se! of assumptions for exogenous variables. Some of the exogenous variables include per capita GDP, exchange rata, consumer price index, crufe oll price and poputatian. Prolections for macro ecanomic variables such as real GDP, consumer price Index (CPi), exchange rales and population wera obtained fom the 20D4 Wortd and US Agricultural Oullook published by the Food and Agricultural Poilcy Research Institute (FAPRI, 2004). The GDP is projected to grow at an annual rate of 5.5\% between 2003 and 2015. During the next 10 years, the exchange rate is projected to appreciate in the initial years and depreciate towards the later period. The population grawh is projected to decline from 1.50\% in 2003 io 123 in 2014 . Frojectians for intemational prices for crude oil, wheat, rice, corn and groundnut were also taken from the same source. Projections for competing crop prices were dbtained by regressing domestic prices on thelr respective international prices. Projections for textile and food price indices were obtained by the regression of these indices an CPI.

\section{Baseline projections}

Baseline projections generally assume the continuation of the current policles ineluding MFA qutolas in textila and apparel exports. The baseline projections were developed by linking the Indla modet to the wortd fibre madel of Texas Tech University (Pan ot al., 2004). The baselina projections shaw that the total textile consurnption is projected to rise by $30 \%$ fram 4803 thousand metric tons (TMT) in 2004 to E224,36 TMT in 2014, partly due to rising per capita consumption. Per capita textle consumplion is projected to increase by about $14 \%$ in the next 10 years, primarily driven by strong income growh. Rising textile consumption will tesult in higher mill use of raw fibre, with coiton and man-made fibre mill use increasing by 13 and $72 \%$ respectively.

Duting the baseline period, the domestic fibre prices are projected to rise sleadily. As shown in Table 1, the cotton price is expected to rise fram 52.50 rupees per kllogram in $2004 / 2005$ to 64.65 rupees per kilogram in 2014/2015, whtereas the polyester price increases from 77.78 rupees per kilogtam to 88.25 rupees per kilogram during the seme period. Cotten production, on the regional basts, is projected to increase by 8\% (from 432 TMT to 467 TMT) in the northem region, by 24\% (from 1739 TMT to 215B TMT) in the central region, and by $16 \%$ (from 890 TMT to 1034 TMT) in the southern regien during the same periad (Table 2a). The total cotion production, on the ather hand, is projected to rise by $19 \%$ from 3180 TMT in 2004/2005 to 377a TMT in 2014/2015 (Table 2b). As expected, most of the production growth is projected to come from yiedd improvements rather than area expansion. Aithough total cotton area Is projected to be flat in the nexi decade, shift in the colton area among the reglons is likely to happen based an ratative profitablity among crops. An incraase in cotton area in the centrat region is projected to be offset by dectinte in area in the other two regians.

Table 1. Effects of MFA quota ellmination on Indian fibre consumption and fibre prices $2004 / 2005$ 2005/2006 2006/2007 2007/2008 2008/2009 2009/2010 2010/2011 2011/2012 2012/2013 2013/2014 2014/2015 Average

Coiton Thousand metric tons

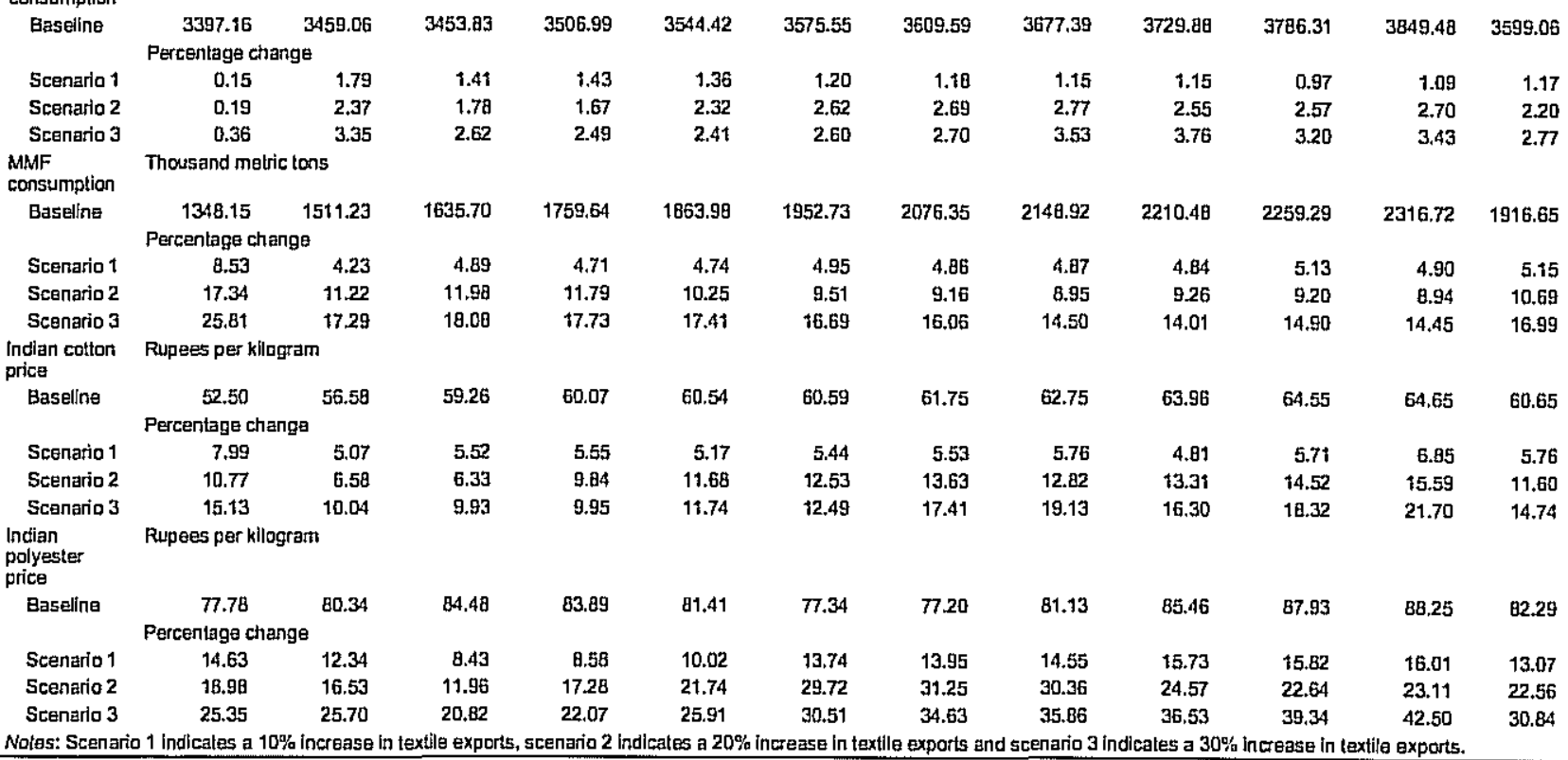

Table 2. Effects of MFA quota elimination on fibre production

Panel A

Northem

cotton

production Easeline
(1000MT) $2004 / 2005$ 2005/2006 2006/2007 2007/2009 2008/2009 2009/2010 2010/2011 2011/2012 2012/2013 2013/2014 2014/2015 Average

Scenario 1

$432.35 \quad 452.91$

$465.17 \quad 47120 \quad 472$

0.21

470.79

468.67

467.49$$
0.00
$$

0.02




\begin{tabular}{|c|c|c|c|c|c|c|c|c|c|c|c|c|}
\hline Scenario 2 & 0.00 & 1.10 & 0.85 & $0.4 \theta$ & 0.47 & 0.38 & 0.20 & 0.04 & -0.23 & -0.38 & -0.38 & 0.23 \\
\hline Sceлario 3 & 0.00 & 1.54 & 1.25 & 0.75 & 0.24 & -0.04 & -0.26 & -0.08 & -0.05 & -0.44 & -0.50 & 0.22 \\
\hline \multicolumn{13}{|l|}{$\begin{array}{l}\text { Central cotton } \\
\text { production }\end{array}$} \\
\hline \multirow{2}{*}{$\begin{array}{l}\text { Baseline } \\
\text { (1000MT) }\end{array}$} & 1739.08 & 1779.26 & 1817.94 & 1869.16 & 1908.35 & 1945.31 & 1981.04 & 2024.02 & 2067.98 & 2114.18 & 2158,25 & 1945.87 \\
\hline & \multicolumn{12}{|c|}{ Percentage change } \\
\hline Scenario 1 & 0.00 & 1,61 & 1.21 & 1.22 & 1.18 & 1.06 & 1.05 & 1.03 & 1.03 & 0.85 & 0.94 & 1.02 \\
\hline Scenario 2 & 0.00 & 2.17 & 1.58 & 1.41 & 2.03 & 2.35 & 2.41 & 2.53 & 2.33 & 2.31 & 2.42 & 1.96 \\
\hline Scenario 3 & 0.00 & 3.05 & 2.38 & 2.22 & 2.13 & 2.36 & 2,41 & 3.17 & 3.42 & 2.90 & 3.04 & 2.46 \\
\hline \multicolumn{13}{|l|}{$\begin{array}{l}\text { Southern } \\
\text { cotlon } \\
\text { praduction }\end{array}$} \\
\hline \multirow{2}{*}{$\begin{array}{c}\text { Basetine } \\
\text { (1000MT) }\end{array}$} & 690.42 & 934.17 & 908.97 & 935.69 & 951.42 & 964.69 & 975.43 & 991.34 & 1006.15 & 1021.88 & 1034.36 & 964.96 \\
\hline & \multicolumn{12}{|c|}{ Percentage change } \\
\hline Scenaria 1 & 0.00 & 2.49 & 1.71 & 1.86 & 1.83 & 1.66 & 1.69 & 1.69 & 1.73 & 1.42 & 1.65 & 1.61 \\
\hline Scenario 2 & 0.00 & 3.35 & 2.22 & 2.13 & 3.24 & 3.74 & 3.89 & 4.16 & 3.84 & 3.93 & 4.19 & 3.15 \\
\hline Scenario 3 & 0.00 & 4.71 & 3.39 & 3.34 & 3.28 & 3.76 & 3.88 & 5.32 & 5.73 & 4.81 & 5.29 & 3.96 \\
\hline \multicolumn{13}{|l|}{ Panel B } \\
\hline \multicolumn{13}{|l|}{$\begin{array}{l}\text { Total cotton } \\
\text { production }\end{array}$} \\
\hline \multirow[t]{2}{*}{$\begin{array}{l}\text { Baseline } \\
\text { (1000MT) }\end{array}$} & 3180.48 & 3284.97 & 3310.70 & 3394.68 & 3450.53 & 3499,42 & 3543.77 & 3601.48 & 3659.62 & 3721.51 & 3777.90 & 3493.19 \\
\hline & \multicolumn{12}{|c|}{ Percentage change } \\
\hline Scenario 1 & 0.00 & 1.69 & 1.23 & 1.25 & 1.19 & 1.04 & 1.03 & $1.0 t$ & 1.02 & 0.83 & 0.95 & 1.02 \\
\hline Scenario 2 & 0.00 & 2.28 & 1.59 & 1.43 & 2.08 & 2.39 & 2.45 & 2.57 & 2.34 & 2.35 & 2.48 & 2.00 \\
\hline \multirow{2}{*}{\multicolumn{13}{|c|}{$\begin{array}{l}\text { MMF } \\
\text { production }\end{array}$}} \\
\hline & & & & & & & & & & & & \\
\hline \multirow[t]{2}{*}{$\begin{array}{c}\text { Baselina } \\
\text { (1000MT) }\end{array}$} & 1640.02 & 1747.94 & 1847.88 & 1963.02 & 2093.28 & 2174.96 & 2296.19 & 2361.13 & 2423.02 & 2481.92 & 2537.90 & 2142.49 \\
\hline & \multicolumn{12}{|c|}{ Percentage change } \\
\hline Scenario 1 & 2.56 & 2.25 & 1.93 & 1.57 & 1.16 & 0.83 & 0.50 & 1.49 & 0.12 & 0.43 & 0.65 & 1.23 \\
\hline Stengrio 2 & 2.56 & 2.25 & 2.34 & 2.66 & 2.16 & 1.77 & 1.38 & 2.35 & 2.08 & 1.24 & 2.90 & 2.21 \\
\hline Scenario 3 & 3.80 & 3.75 & 4.40 & 4.60 & 3.53 & 4.98 & 4.33 & 4.16 & 4.17 & 4.28 & 4,44 & 4.22 \\
\hline
\end{tabular}

Average cotton yield, one of the lowest in the worid, is projected to increase by around $18 \%$ in tha next decade, primarily because of expected adoption of Bt (Bactilus thuringiensis) cotion at a larger scale. This is fairly conservative consldering the findings of ICAC (2004), which concluded that Bt cotton adoption could increase yieid as muct as 50\%.

Currenily, India is a net Importer of cotton and net exporter of man-mada fibres. Sirong domestic fibre dernand in the future, fueled by rising textile exports, is fikely to make india a growing net Importer of collon and a declining net axporter af man-made fibres. Cotton net imports are projected to rise by $27 \%$ from 115 TMT in $2004 / 2005$ to 197 TMT In $2014 / 2015$. Similarly, man-made fibres' net exports are projected to declina by $24 \%$ from 292 TMT to 221 TMT during the same period (Table 3).

Table 3. Effects of MFA quota ellmination on fibre trade and world prices 2004/2005 2005/2008 2006/2007 2007/2008 2008/2009 2009/2010 2010/2011 2011/2012 2012/2013 2013/2014 2014/2015 Average Cotion nat Thousand matric tons

imports

\begin{tabular}{|c|c|c|c|c|c|c|c|c|c|c|c|c|}
\hline Easeline & 155.62 & 167.88 & 169.11 & 169.00 & 168.56 & 167.95 & 167.65 & 187.32 & 18724 & 107.15 & 197.06 & 174.96 \\
\hline & \multicolumn{12}{|c|}{ Percentage changa } \\
\hline Scenario 1 & 3.20 & 3.81 & 4.78 & 4.71 & 4.30 & 3.96 & 3.78 & 3.23 & 2.95 & 3.11 & 3.17 & 3.73 \\
\hline Scenaria 2 & 3.96 & 4.24 & 5.02 & 5.98 & 6.19 & 5.98 & 6.06 & 4.98 & 5.05 & 5.28 & 5.20 & 5.27 \\
\hline Stenario 3 & 7.73 & 6.41 & 6.09 & 6.60 & 7.40 & 6.56 & 7.72 & 7.00 & 6.32 & 6.75 & 7.13 & 6.89 \\
\hline $\begin{array}{l}\text { MMF net } \\
\text { exports }\end{array}$ & \multicolumn{12}{|c|}{ Thousand metric tons } \\
\hline Baseline & 291.88 & 236.71 & 212.19 & 203.38 & 229.31 & 222.22 & 219.64 & 212.21 & 212.54 & 222.62 & 221.26 & 225.83 \\
\hline & \multicolumn{12}{|c|}{ Percentege change } \\
\hline Scenario 1 & -24.98 & -10.39 & -20.85 & -25.63 & -27.96 & -35.37 & -40.71 & -32.71 & -48.97 & -47.31 & -43.84 & -32.61 \\
\hline Scenario 2 & -65.69 & -55.01 & -71.97 & -76.34 & -63.61 & -66.27 & -72.08 & -64.49 & -72.57 & -72.87 & -60.40 & -67.39 \\
\hline Scenario 3 & -97.87 & -82.66 & -101.03 & -108.97 & -109.20 & -97.90 & -106.47 & .100 .61 & -98.19 & -103.51 & -100.30 & $-100,62$ \\
\hline A-index price & \multicolumn{12}{|c|}{ Cents per pound } \\
\hline Baseline & 64,40 & 63.09 & 61.94 & 61.86 & 62,44 & 63.22 & 64.51 & 65.91 & 66.94 & 67.46 & 67.46 & 64.47 \\
\hline & \multicolumn{12}{|c|}{ Percentage change } \\
\hline Scenaria 1 & $0.2 \theta$ & 0.05 & 0.04 & 0.04 & 0.03 & 0.03 & 0.03 & 0.02 & 0.02 & 0.02 & 0.02 & 0.05 \\
\hline Scenario 2 & 0.52 & 0.08 & 0.07 & 0.07 & 0.06 & 0.05 & 0.04 & 0.04 & 0.04 & 0.04 & 0.03 & 0.09 \\
\hline Sctenario 3 & 0.58 & 0.08 & 0.08 & 0.07 & 0.07 & 0.06 & 0.05 & 0.04 & 0.04 & 0.04 & 0.04 & 0.10 \\
\hline
\end{tabular}

\section{Simulation results}

After developing the baseline, alternete scenarios were performed for three different levels of textile exports at 10, 20 and 30\% above the baseline level. Scenarios 1,2 and 3 refer to 10, 20 and 30\% increases in lextlle exports, respectively, due to MFA quota elimination. Simulation results, expressed as a percentage change from each year's baseline level, are summarized in Tables 1-3.

As shown in Table 1, the increase in lextia exports dua to quota ellminations raises the domestic mill use of raw fibres in India. Cotton and man-made fibre milt use are projected to increase each year by an average of 1.2 and $5.1 \%$, respectively, over their respective bases in scenatio 1 (10\% increase in textile exports).

In the case of a $30 \%$ increase in textile exports (scenario 3), cotion and man-made fibre mill use are projected to rise each year by an average of 2.8 and $17^{\text {th }}$, respectively, relative to the baseline leveis. Expansion in the mill demend for fibres should increase fibre prices, with cotton and polyester prices rising as mucti as 22 and $43 \%$, respectively. In the case of scenario 1. coilon and man-ibre prices are projected to be higher each year by an average of 5.8 and $13.1 \%$, respectively, over their respective bases. The effects on fibre prices are much higher (an average of $14.7 \%$ for colter and $30.8 \%$ for man-made fibres each year relative to their baseline levels) for scenario 3 , where textile exports increasa by $30 \%$, 
An incraase in fibre prices should induce higher production levels of catton and man-made fibres. As shown in Tabie 2(a), cotlon production is projected to Incraase the least, each year by an average of $0.06,0.23$ and 0.22 abqve the baseline lavel, ln the northem region, while the cotton production is highest in the squthern region, where it is projacted to increase each year by an average of $1.6,3.15$ and 3.96 above the baseline level in scenarios 1,2 and 3 , fespectively. However, the lotal cotion production is projected to increase each year by an average of 1,2 and $2.5 \%$ above the baseline level in sceniarios 1,2 and 3, respectively. Almast all the production growih ls projected to come from the calton acreage expansion in response to higher prices, with litte la na change ln yield. The northern region accounts far mast of the increase in colton acreage followed by the southern and central regions.

In the case of man-made fibre, production is projecled to be higher each year between 1 and $4 \%$ (Table 2b), depending on the level of textile exports. In scenario 1 , the average annual production increase aach year is estimated to ba $1.2 \%$ as compared to $42 \%$ over their respective bases in scenario 3 . Most of the increases in man-madie ibre production in the initial years come from a higher utilization of existing capacity rather than bultding additionel capacity. However, capacity is projected to rise towards the second half of the projection period, contributing to higher man-mada fibre production.

Since the expansion in domestic colton proctuction is not enough to meet the rising mill demand, imporis are projected to be higher than the baseline level. Cattor imports in scenario 1 are estimated to be approximately $3-5 \%$ higher then the baseline level with an average Increase of $3.7 \%$ oach year over its respective base (Table 3). Similarly, higher textie experis are

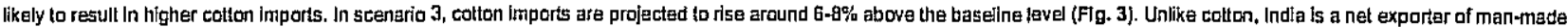
fibres and with rising mill use, its exports are projected to be lower In the scenarios (Table 3). In scenario 1, man-rinade fibre net exports are projected to decilne by as much as $50 \%$, with an average decline of $33 \%$ each year relative to the beseline level. Sirnilarly, in scenaric two (20\% increase in textile exports), man-made fitere net exports are projected to decline each year by an average of $67 \%$ compared to its baseline level during the period 2004/2005 to 2014/2015. As shown in Flg. 4, India is projected to transform from a net exporter to a small net importer of man-mede fbres, with the $30 \%$ increase In textife exports.

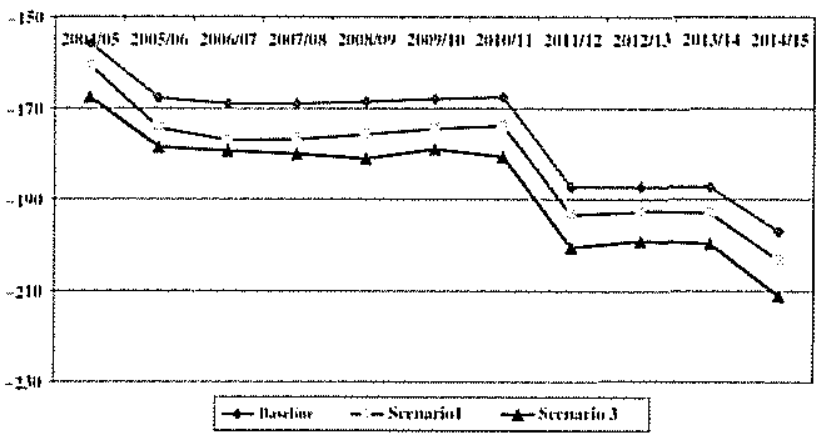

[Enlarge Image]

Fig. 3. Indian cotton net trade projections (baseline vs. scenarios)

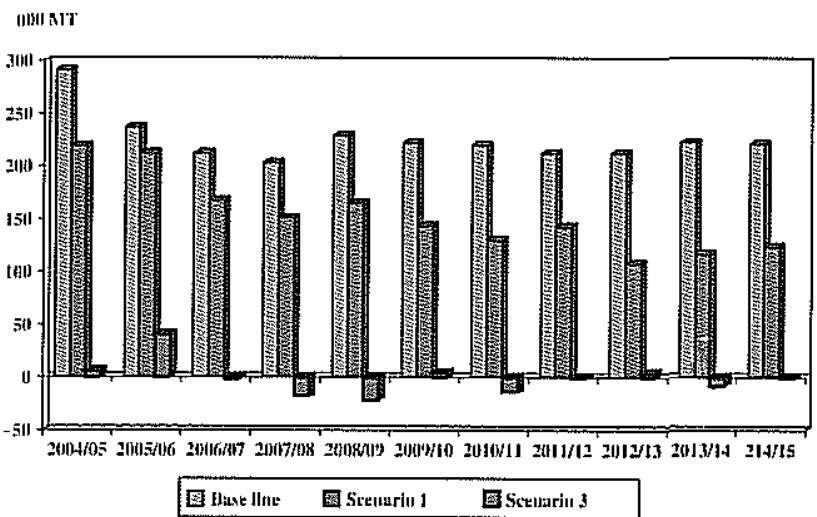

[Enlarge Image]

Fig. 4. Indian man-made fiber net trade projections (baseline vs. scenarios)

The wortd cotton price is estimated to lncrease by one-half of a percent in the first year of simulation for scenario 2 (Table 3). However, adjusiment by the competitors, who boost production, takes away most of the price incraase afler the initial year. For the remaining period, the world prica is projected to incrassa by less than $0.05 \%$, The effects on wortd prices are similar for scenarios 1 and 3.

Overall, the simulatian results suggest thet elimination of MFA quotas ara likely to lead to higher catton imports by India. In addition, man-mada fibre exports from india are projected to decine slgnificantly with the opening of textile markets in the developed countries. Higher domestic cotion prices encourage acreage expansion in cotton in all three regions but not enough to meel rising mill demand tinder the scenerios of higher taxtile exports.

\section{Conclusion}

The cotton supply response being price-inelastie in Indla and given that yield is expected to increase crily merginally during the next decade, increase in calton production is not expected to be sufficient to meet the rising demand. Thus, It is likely that India would continue to rely heavily on cotton imported from other countries. Restits of the study also suggest that manmade fibre production in India would be increasing over the next decade. Currenty, India is a nat exporter of man-made tibres. Sirong domestic fibre demand in the fusture, fueled by rising textile exports, is llkely to make Indla a declining net exporler of man-made fibres. 
From Indian perspective, the resuits provida important insight into course of action that could potentially prevent India from becoming a net importer of cotton. in India, production of cotton needs to grow at a much faster pace than the historical rate to be able to meet domestic demand in the future. Since production increase through area expansion is limited, policies should ba directed to improving productivity and quality. In order to achieve this, management practices encouraging widespread adoption of high-yielcing varieties of cotton and new technologies must be promoted. In addition, improvement in fibre qualty is also essential to meat the demend of high-quaiity cotten by expori-otiented textile mills.

\section{Appendix \\ Empirical Results}

Fibre supply model

The regional cotton acreage madels wera estimated using OLS for the period 1970 to 2003. The ad utusted $R^{2}$ for the cotlon acteage modeis for northern, centrat and southern regions are $0.73,0.62$ and 0.49 , respactively. The estimated parameters along with the diagrostic stalistics are presented in Table A1. Table A2 describes the definition of the variables used in the Incian fibre model. The cotton acreage was specified as the function of the expected prices of cotton, expected prices of competing crops and lagged acreage.

Table A1 Parameters estimates of Indian fibre model

\begin{tabular}{|c|c|c|c|c|}
\hline \multicolumn{2}{|l|}{ Equations } & \multirow[t]{2}{*}{ Ad]. $R^{2}$} & D-W statistics & D-H statistics \\
\hline & & & & \\
\hline Northern & 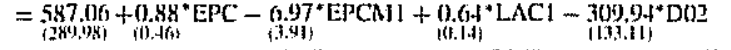 & 0.73 & & 1.92 \\
\hline Central & 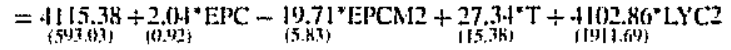 & 0.62 & 1.70 & \\
\hline Southern & 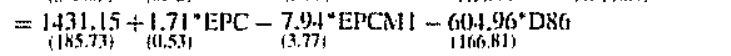 & 0.49 & 2.50 & \\
\hline \multicolumn{5}{|l|}{ Cotton yield } \\
\hline Narthern & 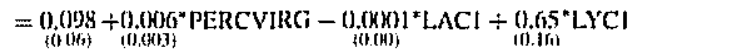 & 0.37 & & -2.34 \\
\hline Central & 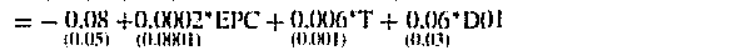 & 0.72 & 1.38 & \\
\hline Southern & 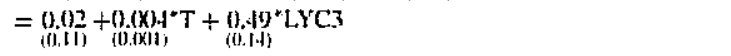 & 0.91 & & $-1,28$ \\
\hline \multicolumn{5}{|l|}{ Man-made fibre } \\
\hline Production capacity & 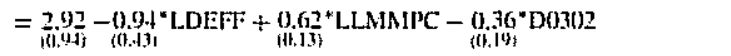 & 0.94 & & -0.30 \\
\hline Ulitization rate & 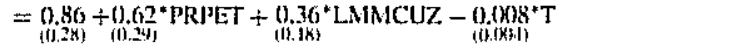 & 0.44 & & -0.63 \\
\hline \multicolumn{5}{|c|}{ 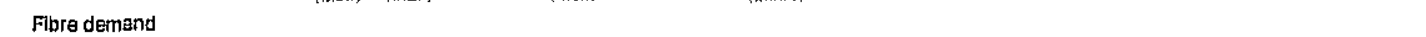 } \\
\hline Textile consumption & 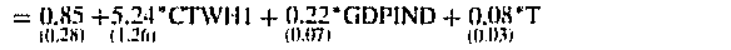 & 0.96 & 1.29 & \\
\hline Cotton share & 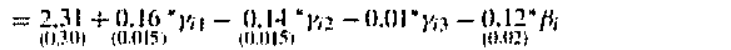 & & & \\
\hline Man-made fibra share & 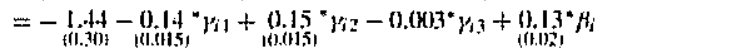 & & & \\
\hline Coitton exports & 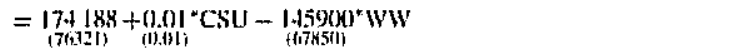 & 0.11 & 1.83 & \\
\hline Cotton imparts & 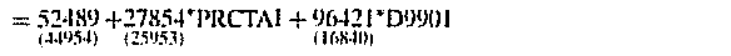 & 0.59 & 1.83 & \\
\hline Man-made fibre net Trada & 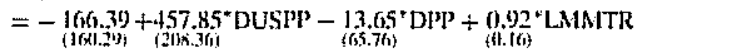 & 0.88 & & 1.22 \\
\hline Colton ending stocks & 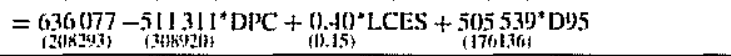 & 0.40 & 1.79 & \\
\hline
\end{tabular}

\section{Table A2 Variable definition}

\begin{tabular}{|c|c|}
\hline Variables & 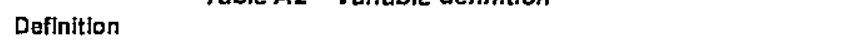 \\
\hline csu & Total cotton supply \\
\hline CTWH1 & Food price index/textile price Index \\
\hline D01 & Dummy variable for 2001 \\
\hline $\mathrm{DO2}$ & Durnmy variable for 2002 \\
\hline 00302 & Dummy $2003+$ Durnmy 2002 \\
\hline D86 & Dumny variable for 1986 \\
\hline 095 & Dummy variable for 1995 \\
\hline D9901 & Dummy 1999 + Dummy 200t \\
\hline DPC & Deflated damestic price of cotton \\
\hline DPP & Deflated domestic polyester price \\
\hline DUSPP & Defleted US 1.5 denier polyester price \\
\hline EPC & Expected price of cotton \\
\hline EPCM1 & Expected price of rice \\
\hline EPCM2 & Expecled prica of groundinut \\
\hline GDPIND & Per capita gross domestic product \\
\hline LAC1 & Northem Indla colton acreage lagged ons year \\
\hline LCES & Cotton endings stocks lagged one year \\
\hline LDEFF & $\begin{array}{l}\text { Log of polyester price lagged } 3-6 \text { years } \\
\text { log of cude oil price lagged } 3-6 \text { years }\end{array}$ \\
\hline LLMMPC & Log of man-made fibre production capacity lagged one year \\
\hline LMMCUZ & Man-made fibre capacity utilization lagged one year \\
\hline LMMTR & Man-mada fibre trade lagged 1 year \\
\hline LYC1 & Northern lndia cotton yield lagged 1 year \\
\hline LYC2 & Central India cotton yield lagged 1 year \\
\hline LYC3 & Southern India cotion yield lagged 1 year \\
\hline PERCVIIRG & Percentage area covered under irrigation \\
\hline PRCTAI & Deflated domestic prica of cotton/deflated and adjusted A-index price for tarifl and exchange rale \\
\hline PRPET & Poiyester price/crute dil price \\
\hline$T$ & Time trend \\
\hline WW & Deflated damestic price of cottonideflated and adjusted A-index price \\
\hline$\beta_{1}$ & Coefficient associaled with expenditure in ith share equation \\
\hline
\end{tabular}




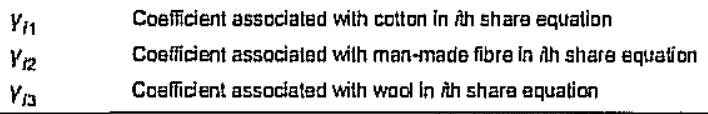

For the northern region, in addition to expected price of colton (EPC), expected price of rice (EPCM1) as the compeling crops, lagged cotton acreage (LAC1), a dummy variabie (DO2) was included to represent drought in 2002. Cotlon acreage for ceniral region was specified as the function of expected price of cotton, price of groundnut (EPCM2), a time trend ( $T$ ), and previous year's cotton yield (LYC2). The specification of cotton acreage in southern region Includes the expected prices of cotton and rice and a dummy variable for 1986 (DEG) to account for the drought experienced in that year. Alt the coefficients are statistically significant and have expected signs. The statistically significant coefficient on the lagged cotton acreage (LAC1) demonstrates fixity in cottan production in the northern region. Low $R^{2}$ 's in all the three regians are meinty dute to the use of expected prices instead of regional net return.

To obtain further insight, the point estimates for own and cross prices were converted into elesticities at the semple means. The estimates for regional own- and cross-price acreage elasticilies are reported In Tabla A3. A5 expected, all the own-price elasticities ara found to be positive and ranga from 0.15 to 0.36 , with tha highest for the southern region and the lawest for the central region.

Table A3 Elasticities of Indlan regional cotton acreage model
at sample mean

The estimated parameters along with the diegnostic for regional cotlon yield equations are raported in Tabie A1. The yield equation in the northern region was specitied as the function of the percentage of area under irrigation (PERCVIRG), lagged cotton acreage (LAC1) and lagged cotton yield (LYC1). In addition to the expected price of cotion, a time trend ( $T$ ) and dummy variable for 2001 (DO1) were also induded in the cotton yleld equation for central region. The estimated coeificient on time irend ( $T$ ) is statistically significant and positive, implying that yields have increased over time and it is likely due to varietal and technological improvemenis in the certral region. Do1 captures the effect of sudden decreasa in yields in the 2001 crop season. Similarly, cotten yield equation in the southem region included time irend ( $\Pi$, and yield-fagged 1 year (LYC3) variables. The coefficients on the bath these variables are statistically slgnificant with positive signs, which Imply that improved tectunalogy and yield realized in the previaus year influence the turrent catton yields in this region. The coeficient of expected price of collon was found to be positive and statisticaliy significant only for the central region. For the other two ragions, results suggest a lesser rola of prica in influencing the yiedd level. The statistically slgnificant and negative coefficient for the lagged cotton acreage in the nortiem region yield equation suggests that the average yiedd in the northem region has dectined as the marginal lands were brought into the cotton production. The adjusted $R^{2}$ values range from 0.37 to 0.91 , with the highest for the southern region and the lowest for the northem region. The possible catuse of the low adjusted $R^{2}$ value in the northem region may be that wealher variablity is mora severe, and monsoon rainfall is erratic which are not being capturect by the model.

Man-made fibre production is calculated as the product of production capacityand utilization rate. The man-made fibre production capacity is specified as the tunction of the ratio of three ta six year lagged prices of polyester and crude of (LDEFF) and production capacity legged one year (LLMMPC). Simllarly, the man-made fibre capacity utilization rate is explained by the ratio of prices of polyester and crude oll (PRPET), as well as one year lagged capacity utilization (LMMCUZ). The lag structure in the production capacity aquation was detemined using Akalke information criterion (AIC). The estimated paramelers along with the diagnostic statistics are reporled in Table A1. The legged-dependent Veriables (LLMMPC for capacity and LMMCUZ for utilization rate) are found to be statistically significant in both of these equations, implying high degree of fixity in man-made fibre production process. The adjusted $R^{2}$ values are 0.94 and 0.44 for capacity and capacity uțilization equations.

\section{Fibre demand models}

The fibre demand was derived using a two-step process. In the first step, Indian per capita texile constumption in fibra equivalent was estimated, and then ft was aliecated among the raw fibres in the second stage to derive the mill use of indlvldual fibres. The per capita textile consumption was estimated using OLS for the period 1970 to 2003 . The consumption equation was specified as the function of per capita real GDP (GDPIND), the ratio of food price index to (extle price index (CTWH1\}, and a time trend variable (J). Time trend variable was added in the equation ta capture the rise in textile consumption over time. The estimeled parameters along with the diagnostic statistics are presented In Tahle At. All the confficients are statistically significant and have the expected signs. Results show that the income variable is found to be dominart in determining per capita textile consumption in India. The Income elasticity calculated at the sample mean is 0.74 . The statistically significant and positive caeficient for the price ratio suggests that an increase in the ratio, eilher due to rise in food prica Index or dectine in textila price index, increases textile consumption and vica versa. The statistically significant trend variable ( $T$ ) show that factars other than income and popufation such as greater choices of textile products and brand name availability because of textile and apparel trade liberalizations, and shift In consumer preferences in India can be attributed to increase in textile consumption. The adjusted $R^{2}$ for this model is 0.96 .

In the second stage, total textile demand was allocaled among compeling fibres, i.e. cotion, wod and man-made fibres using the AIDS demand systam. The demand system was estimated using noninear SUR with symmetry and homogeneity imposed. The wool equation was crnilted from the estimated system and was later obtained through the adding-up constraint. The estimated parameters along with standard errors are presented in Table A1. All the estimaled parameters ere statistically slgrificant at the f\%, level. The coefficients for the estimated parameters of the total fbre expenditures are fotnd to be negative for cotion and wool, and positive for man-made fibres.

The estimated parameters were converted into price and expenditure elasticities at the sample mean and ate reported in Tables A4 and A5. As expected, all the expenditure elasticities are positive and range between 0.47 and 1.39. Interestingly, expenditure elasticty for man-made fibre was found to be hlghly elastic as compared to colton and wool. All uncompensated own-price elasticites ara found to be negative and range from -0.04 to -0.63 , with the lowest for wool and the highest for the man-made fibres (Tab)e A4). Own price eiasticity of cotion is more or lass the same as that of man-made fibre. On the other hand, compensaled own price elasticities in Table A5 are much smalter in magnitude, and range between -0.03 and -0.18 . The positive compensated cross-prica elasticities between cotton and ment-made fibres demanstrate that they ara net substitule at the mill lavel. Sirnilarly, cross-price elasticities between man-made fibres and wod are found to he positive and small, suggesting weaker substitutional relationstilp between these two fibres at the mill Ievel. However, compensated cross-price elasticilies between cotton and woal, and wool and cotton are small and negative, implying weaker complementary relationship between cotton and woal at the mill level.

Table A4 Estimated uncompensated fibre price and income elasticities Demand elastlcttles with respect to the price of

\begin{tabular}{llllr} 
& Cotton & Man-made fibres & Wool & Expenditure elasticities \\
Cotton & -0.63 & -0.18 & -0.02 & 0.82 \\
Man-rnade fibres & -0.73 & -0.63 & -0.02 & 1.39 \\
Wool & -0.36 & -0.08 & -0.04 & 0.47 \\
\hline
\end{tabular}

Table A5 Estimated compensated fibres price elasticities Demand elasticities with respect to the price of 


\begin{tabular}{lrrr} 
& Cotton & Man-made flbres & \multicolumn{2}{c}{ Wool } \\
Cotton & -0.09 & 0.09 & -0.01 \\
Man-made fibres & 0.18 & -0.18 & 0.01 \\
Wool & -0.05 & 0.08 & -0.03 \\
\hline
\end{tabular}

\section{Fibre trade and ending stocks equations}

The equations for cotton exports and Imports were estimated seperately using OLS. Cotton exports equation are specified as the function of domestic to A-index price ratio (WW), and cotton suppiy(CSU) variable to account for the government restrictions on the cotton exports. Cotton imports in Incia are explainad by the ratio of domestic coltion market price to the worid cotton prica (PRCTAI) and a binary variable for 1999 and 2001 (D9901) Jointly to capture the effects of ctange in trade pailcy and price effects. In order to avold multicallnearity between the domestic and the international prices, the ratlo of tomestic to world price was included as the explanalory variable rather then indlvidtsal prices. The world cotton price, represented by the A-index price, was converted into the local currency using the merket exchange rate, and the imporyexport teriffs wera added to the international prices.

The regression resulls alang with the diagnostic statistics are reporled in Table At. The coefficient on the domestic to A-ridex price ratio (WWW) was found to be negative and statistically slgnificant in the colton exporis equation. This implies that the cotton exports from India woutd iscrease as the domestic price of cotton decreases telative to the world price and vice versa. However, the estimated coefticient for the cotton supply variable (CSU) was not statistically different from zero, incicating a lesser role of domestic supply in determining export level. The coefficient on PRCTAl, is howaver, not statisticaliy significantly different fram zera but has the hypothesized posilive sign. The binary variable D9901 captures the effects of change in trade policy on cotton imports for 1999 and 2001. Low $P^{2}$ 's in both the equations ara due to government Intervention in trade through state agencies, which are not being captured by the models.

In the case of man-made fibres, the net trade equation was estimaled rather than separate equations for exporis and imports, primarily because of nonavallabllity of data. The man-mede fibre net trade equation was specified as the function of the international price represented by the US $\mathbf{1 . 5}$ denler polyester price (DUSPP). domestic polyester price (DPP), and man-made fibre net trade legged $t$ year (LMMTR). Since the share of cellutosic fibre is negllgible, the polyester price was used as the representibive price for the man-made fibres. The regression results reported in Table A1 indteate that the coeficient for DUSPP is positive and statistically sigrifficant, whila that for DPP is not statistically significantiy bifferent from zero but hes the expected negative sign. This implles the importance of the international price raller than the domestic price in determining the man-made fibra trade level. The ccofficient for the lagged man-made fibre net trade (LMMTR) is statistically slgniriteant with positive sign, which indicates that man-mada fibra net trade in the previous year infuences the currerit man-made fibre net trade in India. The adjusted $R^{2}$ value of 0.88 suggests that majority of the variation In man-made fibre net trade is explained by the explanatory variables inciuded in the equation.

The estimated parameters and the dlagnostic statistics for the coitlon ending stocks equation are reporled fn Table A1. The ending stacks was explained by coiton price (DPC), beginning stacks (LCES) and a dummy variable for 1995 (D95) to capture the effect of sudden rise in stocks in 1995. The coefficient for DPC is found to be negative and stattstically significant at the $10 \%$ level, suggesting an Inverse relationship between price and canyaver stocks. As hypothesized, the LCES is statistically significant and directly related with the cotton ending slocks. The low $R^{2}$ value for the cotton ending stocks equation is not surprising in the presence of the goveriment procurement program. Historically, more than hall of the carryaver stock is heid by the government.

\section{Model validation}

After estimating all the equabiens, the model was solved simultaneousfy in a simulation program using SAS (stalistical andlysis system). Historical simulation of the model's equations was used to velldate the estimated model using the components of the meen squared error (MSE) and the Theil inequality coefficients. Theil's U statistic performed better than the decomposition of mean squared error. Overall, the model validation statistics suggest that the simulation model has reasconably good forecasting ability.

\section{References}

1. Baffes, J. and Ajwad, MI (2001) ldenllfylng price linkages: a review of the Ilterature and an appllcalion to the world market of cotton. Applled Economics 33 , pp. 1927194t. [nformaworle]

2. Deaten, A. and Muelbauer, J. (1980) An aimost ideal demand system. American Economic Review 70, pp. 312-326.

3. Department of Agricultural Cooperatives, India (2004) Agricultural Statistics - Avaliable at http:llagricoop.תlc.jn/stat/stles!

4. Devadoss, S. and Wahl, T. (2004) Welfare impacts of Indlan apple trade. Applied Economics 36 , pp. 12Bg-1294. [informawarld]

5. Fond and Agricultural Organization (2004) FAOSTAT Database Colleclions - Avaliable at hltp:llfaostat.fao.orglfacstaticollactlons? version=ext\&hasbulk=0\&subset=agrlcult

6. Food and Agricultural Policy Research (2004) FAPRI 2004 U.S. and Worid Agricultural Oullook. Staff Report 1-04, Center for Agricultural and Rural Davelopment Iowa State University, Ames, lowa

7. Fulter, F., Beghin, J., Fabtosa, J.. Mohanty, S., Fang, C. and Kaus, P. (2002) Accessian of the Czech Republic, Hiungary, and Poland to the European Unian: impacts on agricultural markets. The World Ecoriomy 25 , pp. 407-427.

B. Green, R. and Alston, JM (1990) Elasticilies in AlDS model. American Journal of Agricultural Economics 72 , pp. 442-4A5. [ crossref ]

9. International Colton Advisary Committes (ICAC) (2004) Report of the Second Export Panel an Biatachnology of Cotton Washington, DC

10. International Monetary Fund International Financial Statistics, Washington, DC

11. Koo, WW (2002) Alternative US and EU sugar trade Ilberalization policies and their implications. Raviaw of Agricultural Economics 24 , pp. $336-352$.

12. Landes, MR (2004) The elephant is fogging: new pressures for agricuttural reforms In India. Amber Waves Econonic Research Service , USDA - February

13. (2003) The policy simulation model of the Chiness fibre markels, Masters thesis Texas Tech University, Lubbock, TX

14. Mohanty, 5., Fang, C, and Chaudhary, J. (2003) Assessing the competitiveness ot Indian cotton production: a policy analysis matrix approach. The Journal af Cotton Science 7.pp. 65-74.

15. Pan, S., Mohanty, S., Ethridge, D. and Fadiga, M. (2004) Effects of Chinese Currency Appreciation on the Worid Fbre Markets Catton Economics Research Institute, Department of Agricultural and Applied Economics, Texas Tech University, Lubbock, Texas

16. Reserve Bank of India (200t) Handbook of Statistics on Indian Ecanomy CD-ROM database

17. SAS (2002-2003) Version 9.1. SAS Institute Inc. , Cary, NC, USA

19. Textile Commissianer's Office (2003) Prices of various fibms (2003) - Avalfable al http:/ftexmin.nic.in/ermiudelstat.htm

19. United States Deparment of Agriculture Cotton and wool: situation and outlook yearbook. Various issues Washington, DC

20. United States Department of Agricullure (2004) Foreign Agricultural Service , Weshinglon, DC 


\section{List of Figures}

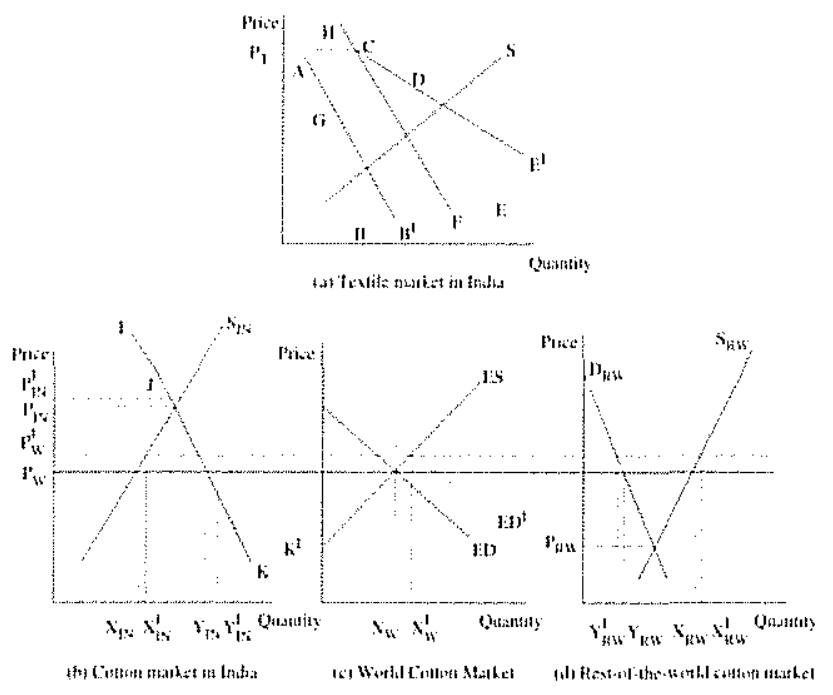

[Enlarge Image]

Fig. 1. Impacts of MFA quota elimination on world cotton and textile markets.

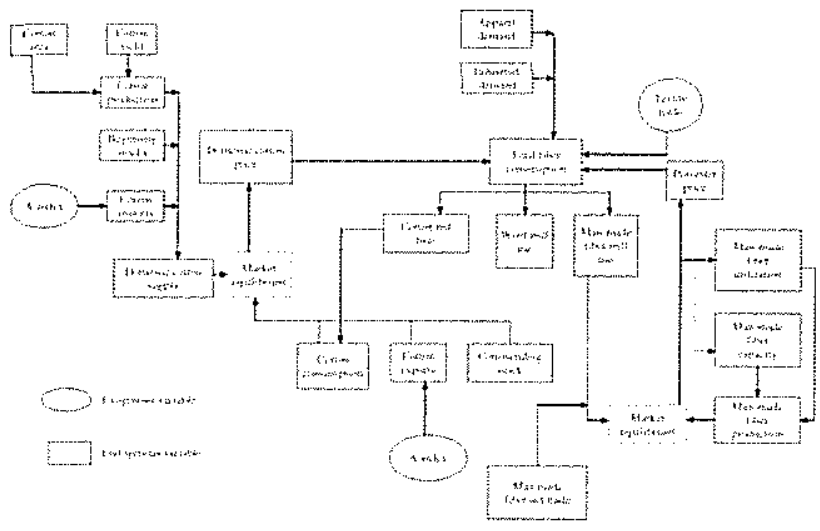

[Enlarge ]mage]

Fig. 2. Schematic representation of the Indian fibre model

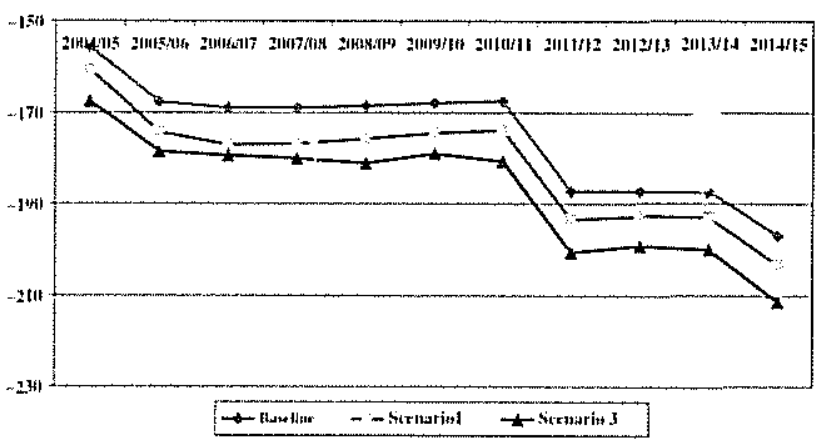

[Enlarge Image]

Fig. 3. Indian cotton net trade projections (baseline vs. scenarios) 


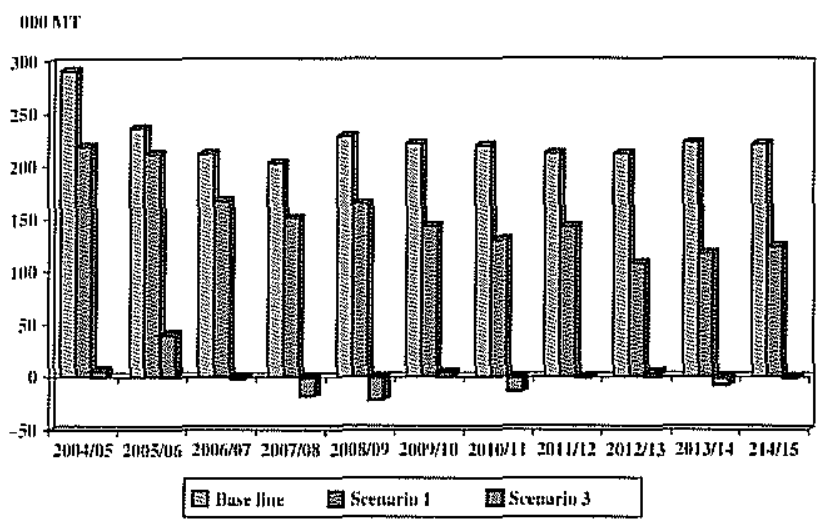

[Enlarge Image]

Fig. 4. Indian man-made fiber net trade projections (baseline vs. scenarios)

\section{List of Tables}

Table 1. Effects of MFA quota elimination on Indian fibre consumption and fibre prices 2004/2005 2005/2006 2006/2007 2007/2008 2008/2009 2009/2010 2010/2011 2011/2012 2012/2013 2013/2014 2014/2015 Average Thousand metric tans

Colton

consumption

Baseline

Scenario 1

Scenario 2

Scenario 3

MMF

constumption

Baseine

$3397.16 \quad 3459.00$

3453.83

Percentage change

$\begin{array}{ll}0.15 & 1.79\end{array}$

$\begin{array}{ll}0.15 & 1.79 \\ 0.19 & 2.37\end{array}$

1.41

Thousand matric tons

Scenario $\mathbf{i}$

Scenario 2

Scenario 3

Incian cotton

price

Baseline

Scenaria 1

Scenario 2

Scenario 3

Indian

polyester

prica

Baseline

1348.15
Percentage change

$\begin{array}{cr}8.53 & 4.2 \\ 77.34 & 11.2\end{array}$

$\begin{array}{ll}17.34 & 11.22 \\ 25.81 & 17.29\end{array}$

1.78
2.62

\subsection{3}

3544.42

3575.55

Rupees per kilogram

$52.50 \quad 56.50$

Percentage change

$\begin{array}{ll}7.99 & 5.07\end{array}$

$\begin{array}{rr}7.99 & 5.07 \\ 10.77 & 6.58\end{array}$

$15.13 \quad 10.04$

1.67
2.49

\subsection{6}

2.32
2.41

1.20

2.62

3677.39

3729.88

3786.31

$3849.40 \quad 3599.06$

Rupees per kllogram

$1635.70 \quad 1759.64$

195.73

2.69

$1.15 \quad 1.15$

2.77

2.55

0.97

2.57

$1.09 \quad 1.17$

$2.70 \quad 220$

5 cenario 1

Scenario 2

$77.78 \quad 80.34$ 77.78 $14.63 \quad 12.34$
16.98

4.89 $\quad 4.71$

4.89

11.98

$4.71 \quad 4.74$

$4.74 \quad 4.95$

10.25

$4.95 \quad 4.86$

9.51
16.69

9.16
16.06

2148.92

2210.4日

2259.29

$2316.72 \quad 1916.65$

18007.73

(17.41

4.87

14.50

4.84
9.26

14.01

5.13

9.20

$4.90 \quad 5.15$

$8.94 \quad 10.69$

$\begin{array}{llllllllll}59.26 & 60.07 & 60.54 & 60.59 & 61.75 & 62.75 & 63.96 & 64.55 & 64.65 & 60.65\end{array}$

$557-55$

$\begin{array}{lll}5.17 & 5.44 & 5.53\end{array}$

11.69

$\begin{array}{lll}5.44 & 5.53 \quad 5.76\end{array}$

$5.76 \quad 4.81$

4.81 $\quad 5.71$

5.71
14.52

6.85

15.59

5.76

$9.93 \quad 9.95$

11.74

12.49

17.41

19.13

16.30

18.32

21.70

14.74

Scenaria 3

$18.98 \quad 16.53$

84.48

83. 89

$81.41 \quad 77.34$

81.13

85.46

87.93

88.25

82.29

$8.43 \quad 8.5$

$10.02 \quad 13.74 \quad 13.95$

$21.74 \quad 29.72 \quad 31.25$

14.55

30.36

15.73

15.82

22.64

36.53

39.34

16.01

23.11

20.82

$22.07 \quad 25.91$

30.51

$34.63 \quad 35.86$

42.50

30.84

Notes: Scenario 1 indicales a 10\% Increase in textile exporis, scenario 2 indicates a $20 \%$ increase in textile exports and scenario 3 ind cates a $30 \%$ increase in textile exports.

Table 2. Effects of MFA quota elimination on fibre production

2004/2005 2005/2006 2006/2007 2007/2008 2008/2009 2009/2010 2010/2011 2011/2012 2012/2013 2013/2014 2014/2015 Average

Panel A

Northern

coitan

production

Easeline
(1000MT)

Scenario 1

Scenario 2

Scenario 3

Central coiton

production

Baseline

(1000MT)

Scenerio 1
$432.35 \quad 452.91$

465.17

471.20

472.13

470.7

Percentage change

$\begin{array}{ll}0.00 & 0.82 \\ 0.00 & 1.10 \\ 0.00 & 1.54\end{array}$

0.66

0.85

0.46
0.48

0.21
0.47

0.24

-0.04
0.38

0.38

0.20

$-0.26$

1739.08 1779.26

1817.94

1869.16

t908.35

Percentage change

0.00

1.21

1.22

1.18

1.06

1.05

1.03

1.03

0.85

0.94

1.02 


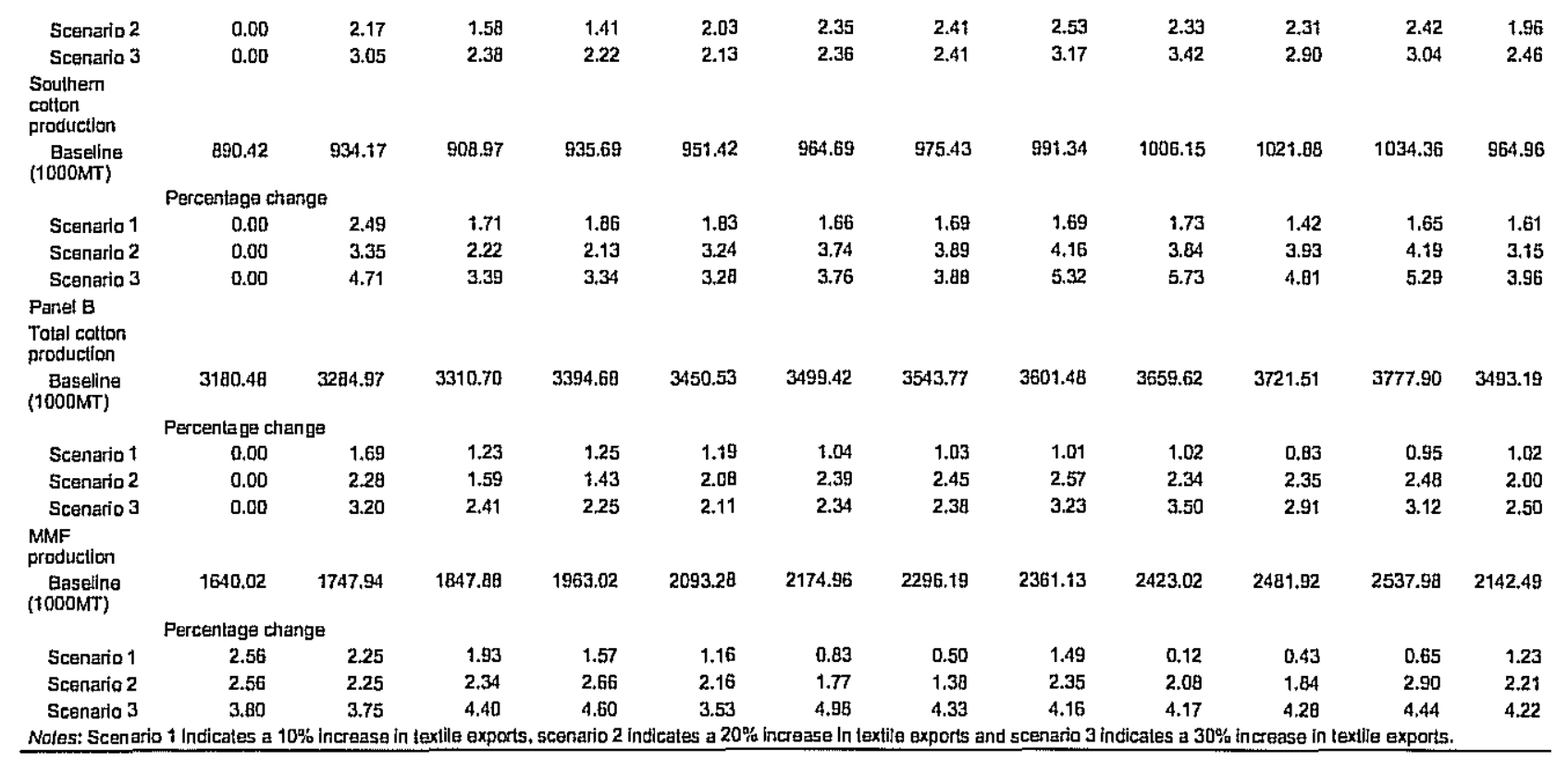

Table 3. Effects of MFA quota ellmination on fibre trade and world prices 2004/2005 2005/2006 2006/2007 2007/2008 2008/2009 2009/2010 2010/2011 2011/2012 2012/2013 2013/2014 2014/2015 Average

Cotton net Thousand metric tons

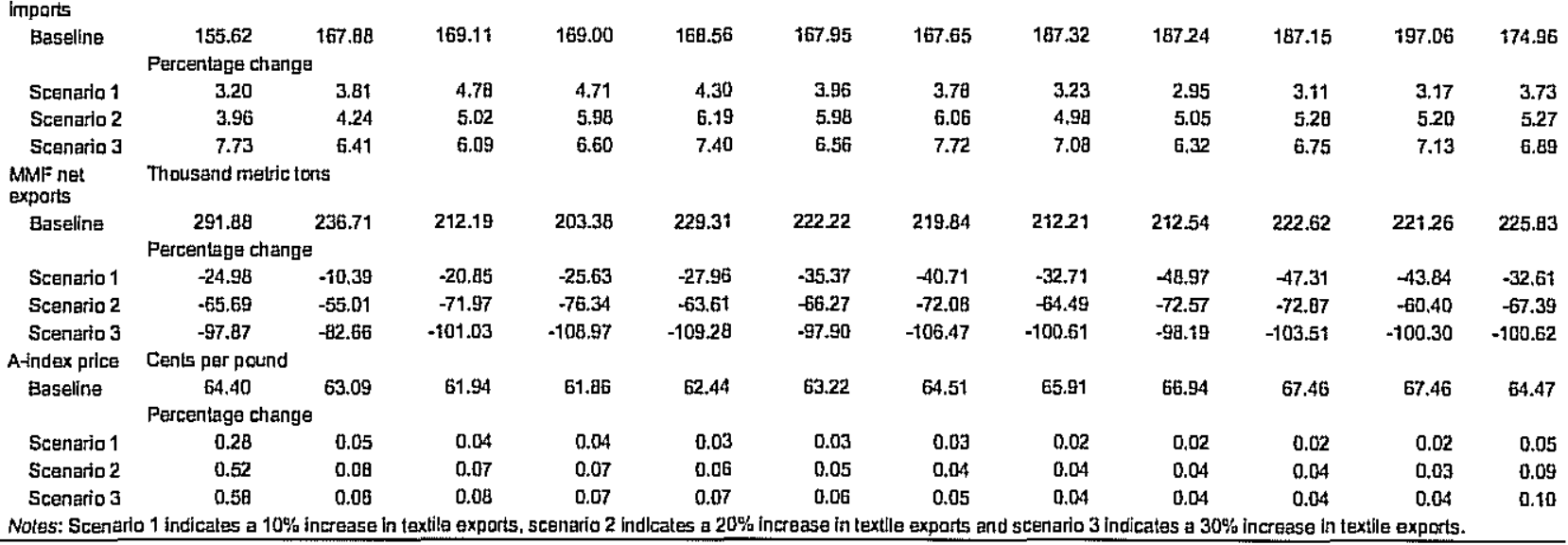

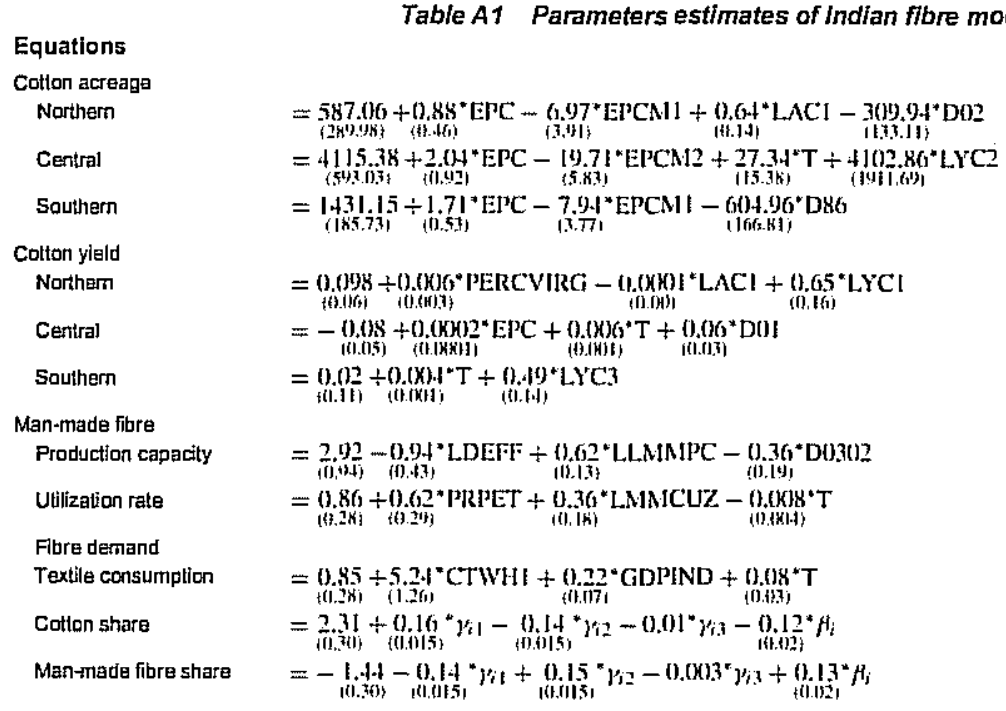

Ad]. $R^{2} \quad$ D-W statistjes D-H statistics

$\begin{array}{lll}0.73 & & 1.92 \\ 0.62 & 1.70 & \\ 0.49 & 2.10 & \\ 0.37 & & -2.34 \\ 0.72 & 1.38 & \\ 0.91 & & -1.28 \\ 0.94 & & -0.30 \\ 0.44 & & -0.63 \\ 0.96 & & \\ & & \end{array}$




\begin{tabular}{|c|c|c|c|}
\hline Cotton exports & 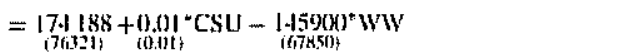 & 0.11 & 1.83 \\
\hline Cotlon imparts & 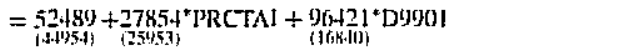 & 0.59 & t.83 \\
\hline Man-made fibre net Trada & 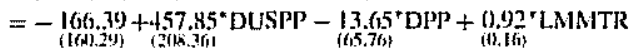 & 0.88 & \\
\hline Coittan ending slocks & 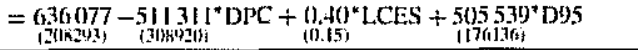 & 0.40 & 1.79 \\
\hline
\end{tabular}

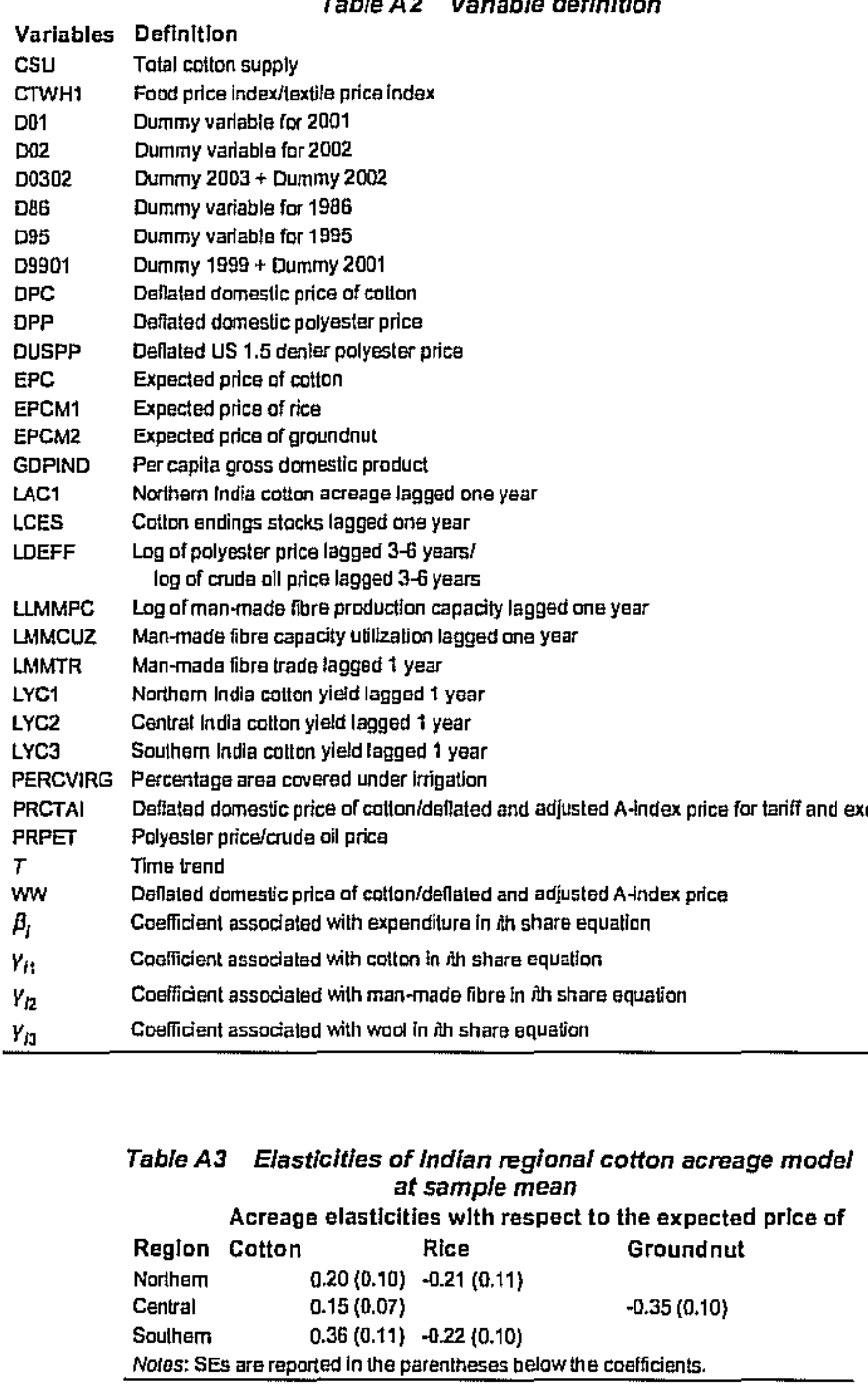

Table A4 Estimated uncompensated fibre price and income elasticities Demand elastlcitles with respect to the price of

\begin{tabular}{lllr} 
Cotton & Man-made fibres & Wool & Expenditure elastlcitles \\
-0.63 & -0.18 & -0.02 & 0.82 \\
-0.73 & -0.63 & -0.02 & 1.39 \\
-0.36 & -0.08 & -0.04 & 0.47 \\
\hline
\end{tabular}

Table A5 Estimated compensated fibres price elasticlites Demand elasticttles with respect to the price of Cotton Man-made flbres Wool

\begin{tabular}{lrrr} 
Cotton & -0.09 & 0.09 & -0.01 \\
Man-made fibres & 0.18 & -0.18 & 0.01 \\
Wad & -0.05 & 0.08 & -0.03 \\
\hline
\end{tabular}

